\title{
Effect of Salinity and Temperature on Germination of Lygeum spartum
}

\author{
Bouzid Nedjimi
}

Received: 29 May 2013/Accepted: 20 September 2013/Published online: 15 October 2013

(C) NAAS (National Academy of Agricultural Sciences) 2013

\begin{abstract}
Lygeum spartum L. (Poaceae) is one of the most important perennial grass species in arid steppes of Algeria. Its germination responses to environmental stresses are poorly understood. Therefore, experiments were conducted to determine the effect of salinity and temperature on the germination of seeds. Seeds were germinated at three alternating temperatures $\left(10-20,15-25\right.$, and $\left.20-30{ }^{\circ} \mathrm{C}\right)$, with four $\mathrm{NaCl}$ concentrations $(0,50,100$, and $150 \mathrm{mM})$ and 12 -h photoperiod. Results indicate that seeds can germinate at high salt concentrations $(150 \mathrm{mM} \mathrm{NaCl})$. However, highest germination was obtained in distilled water. Lower thermoperiods promoted germination, while high temperatures significantly inhibited the germination of seeds at all $\mathrm{NaCl}$ concentrations tested. Rate of germination decreased with increases in salinity. Seeds recovered after being transferred to distilled water, and recovery was higher from higher salinity concentrations and lower thermoperiods. L. spartum is moderately salt tolerant at germination stage, and tolerance is affected by the interaction of temperature and $\mathrm{NaCl}$ concentration.
\end{abstract}

Keywords Lygeum spartum $\cdot$ Germination recovery $\cdot$ Salt tolerance $\cdot$ Steppe

\section{Introduction}

Many arid and semiarid regions in the world have soils and water resources that are too saline for most of the common conventional crop system [23]. Salt-affected soils are widely spread in many arid and semiarid regions of the world and increasingly threatening agricultural expansion and productivity. Yet, in many arid environments, highquality water is not available to support the establishment of plants for revegetation projects. The removal of sodium salts from saline soils by tolerant plants, as an alternative for costly chemical amendments, has emerged as an efficient low-cost technology [9].

\footnotetext{
B. Nedjimi $(\square)$

Laboratoire d'Exploration et de Valorisation des Écosystèmes

Steppiques, Faculté des Sciences de la Nature et de la Vie,

Université de Djelfa, Cité Aîn Chih, BP 3117, 17000 Djelfa, Algeria

e-mail: bnedjimi@yahoo.fr
}

Lygeum spartum L. (Poaceae) is a salt rhizomatous perennial grass ranging in distribution from Northern Africa that can tolerate extreme conditions of aridity, salinity, and high temperatures [23,24]. The plant propagates by rhizome growth after monsoon rains, and it also produces numerous flowers and seeds from April to July [1]. The presence of fibers confers a significant role in the craft industry of the carpets, curtains, and plaits $[14,25]$. The structural and architectural study of foliar fibers of this species has shown the structural diversity of this tissue. Tests of obtaining paper pulp starting from foliar tissues made it possible to confirm that the L. spartum is a paper plant [15].

Lygeum spartum has been especially recommended for arid zone restoration projects. In a field experiment, Rogel et al. [27] demonstrated that $L$. spartum can be used as a bio-indicator of soil salt type. $L$. spartum has been also suggested as a suitable species for the phytoremediation owing to the high translocation rates of $\mathrm{Cd}$ toward the aboveground tissues [4].

In arid and semiarid Mediterranean regions, salinity is one of the most detrimental factors affecting seeds 
germination and plant establishment. An increase in salinity induces both a reduction in the percentage of germinating seeds and a delay in the initiation of the germination process [22].

Germination failures on saline soils are often a result of high salt concentrations in the seed-planting zone because of the upward movement of the soil solution and subsequent evaporation at the soil surface. This has been attributed to both osmotic and toxic effects [16]. Seed germination under saline conditions occurs after high precipitation where soil salinity is usually reduced due to leaching [17].

In arid regions of Algeria, the climate is mainly characterized by low and irregular rainfall in which potential evapotranspiration exceeds precipitation. In these areas, high rate of evaporation causes an accumulation of salts on the surface of the soil. These harsh conditions have led to differential life-history strategies in perennial plants in order to maximize their fitness [13]. In such regions, germination occurs during the rainy season when soil salinity levels are usually reduced [8].

In natural field conditions, stress may be transient and the capacity of the plant to complete its life cycle is directly related to its ability to recover after exposure to stressful period [29]. Sharma and Sen [28] attributed rapid seed germination of Haloxylon recurvum as an adaptive strategy to the availability of water when reduced levels of $\mathrm{NaCl}$ content are reached in soil for short durations during the rainy season. This is because evaporation under full sunlight and higher temperatures causes an increase in the salt content by capillary movement. If a seed can take advantage of a short period of reduction in soil salinity and germinates rapidly, then seedling establishment is ensured.

Little work has been done on the germination strategies of Mediterranean steppe grasses exposed to high temperature and salinity [7]. The present research describes the ability of $L$. spartum seeds to germinate under various thermoperiod and salinity regimes, and evaluate the recovery capacity to this salinity conditions. Based on the distribution of L. spartum, we hypothesize that optimal germination would be maintained at moderate salinities and low temperature regimes.

\section{Materials and Methods}

Seeds of L. spartum were collected from the area of Ain Maâbed in the province of Djelfa (Algeria) $\left(2^{\circ} 39^{\prime} \mathrm{E}\right.$ longitude, $34^{\circ} 50^{\prime} \mathrm{N}$ latitude, and $934 \mathrm{~m}$ elevation). Seeds were separated from each inflorescence (Fig. 1) and sterilized in $10 \%$ sodium hypochlorite (Clorox) solution for $1 \mathrm{~min}$, subsequently washed with distilled water air-dried before being used in the germination experiments. Four salinity concentrations $(0,50,100$, and $150 \mathrm{Mm} \mathrm{NaCl})$ were used based on a preliminary test to determine the salt tolerance limits of the species.

Germination was tested in a programmed incubator at 10-20, $15-25$, and $20-30{ }^{\circ} \mathrm{C}$ dark-light temperature regimes with a $12-\mathrm{h}$ photoperiod.

A completely randomized design was used in the germination tests. Four replicates of 25 seeds each were germinated in twofold of filter paper placed in plastic Petri dishes (9 $\mathrm{cm}$ diameter) with $5 \mathrm{ml}$ of test solution. A seed was considered to have germinated when the radicle emerged. After 15 days, all non-germinated seeds were placed in distilled water and under the initial temperature regimes for another 15 days to determine their ability to recover from salt treatments.

Rate of germination was calculated using a modified Timson's index [30] of germination velocity:

Germination velocity $=\Sigma G / t$

where $G=$ percentage of seed germinated after 2-day interval and $t=$ total time of germination. Rate of recovery germination was calculated by using the relation as follows:

Recovery percentage $=(a-b) /(c-b) \times 100$.

where $a=$ total number of seed germinated (the number of seeds germinated in saline solutions plus those that recovered to germination in the distilled water), $b=$ total number of seeds germinated in saline solution, and $c=$ total number of seeds [17].

Germination data were arcsine transformed before statistical analysis to ensure the homogeneity of variance. Data were analyzed using SPSS version 9.0. A two-way analysis of variance (ANOVA) was carried out to test effects of the main factors and their interaction on the rate

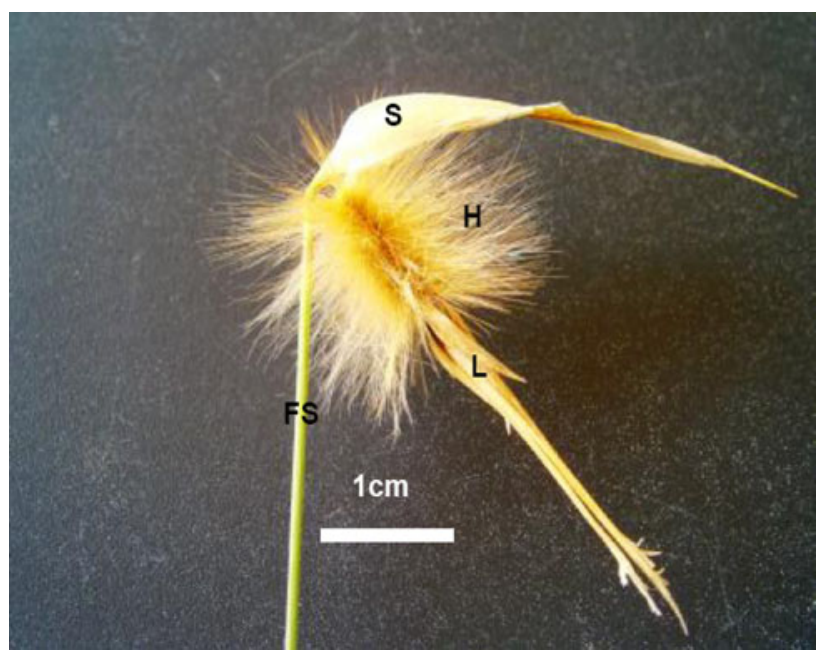

Fig. 1 Mature seed of L. spartum showing numerous unicellular hairs $(H)$, lemma $(L)$, spathe or glume $(S)$, and floral stalk $(F S)$ 
and final percentage of germination. Tukey's test was used to estimate least significant range between means.

\section{Results}

\section{Germination Percentage}

Salinity, temperature, and their interaction significantly $(P<0.001)$ affected the germination percentage of $L$. spartum seeds (Table 1). Germination percentage decreased with increasing salinity, and the highest germination percentage was found in distilled water (Figs. 2, 3). Seeds of $L$. spartum were able to germinate at all temperatures, and the optimal temperature corresponds to 10-20 ${ }^{\circ} \mathrm{C}$ (Fig. 2). The delay of germination increased with increasing $\mathrm{NaCl}$ concentrations and was maximal at the 20-30 ${ }^{\circ} \mathrm{C}$ temperature than with other temperatures.

\section{Rate of Germination}

The index of germination velocity calculated by using a modified Timson's index showed that the rate germination decreased with an increase in salinity (Fig. 4). A two-way ANOVA of the rate of germination indicated a significant $(P<0.001)$ main effect of temperature, salinity, and their interaction (Table 1). The inhibitory effect of salinity on rate germination percentage was greater at $20-30{ }^{\circ} \mathrm{C}$ than at all thermoperiods. Although the increase in salinity decreases the rate germination, the detrimental effect of salinity is generally less severe at optimum germination temperature $\left(10-20{ }^{\circ} \mathrm{C}\right)$.

\section{Recovery of Germination}

After 15 days of salinity treatment, seeds were transferred to distilled water to determine the recovery of germination. Germination recovery of $L$. spartum was significantly $(P<0.001)$ affected by thermoperiod, salinity, and the interaction of both factors (Table 1). Recovery percentages decreased with the increase in the temperature. Germination was higher for seeds exposed to 100 and $150 \mathrm{mM}$ $\mathrm{NaCl}$ at $10-20{ }^{\circ} \mathrm{C}$ compared to those incubated at 20-30 ${ }^{\circ} \mathrm{C}$ (Table 2).

Table 1 A two-way ANOVA of the effects of salinity, temperature, and their interaction on germination of $L$. spartum

\begin{tabular}{lrcc}
\hline Independent variable & Salinity & Thermoperiod & $\begin{array}{l}\text { Salinity } \times \\
\text { thermoperiod }\end{array}$ \\
\hline Percent germination & $22.31^{* * *}$ & $47.10^{* * *}$ & $4.59^{* * *}$ \\
Rate of germination & $52.01^{* * *}$ & $157.319^{* * *}$ & $13.85^{* * *}$ \\
Percent recovery & $276.97^{* * *}$ & $249.27 * * *$ & $47.07^{* * *}$
\end{tabular}

Data represent $F$ values significant at $P<0.001$ (***)

\section{Discussion}

Lygeum spartum, commonly named esparto, is an important perennial grass in semiarid and arid areas in Algeria, with Stipa tenacissima L. and Aristida pungens Desf. This grass makes a natural fence against desert expansion. In addition to its ecological role, L. spartum has an economical interest in traditional craftsmen and paper manufacturing [6]. The conservation of $L$. spartum populations in the Algerian steppes is a very complex task as ecological conditions are not only highly variable but also extreme (low rainfall, high salinity, etc.). Overgrazing, cutting, and farming around steppe related to the increase in rural population have practically eliminated vegetation from the most arid and semiarid steppes [26]. In this context, knowledge of $L$. spartum natural regeneration is a prerequisite to limit out its potential distribution area. Native vegetation present in Algerian steppes is exposed to various stresses including salinity, drought, and extreme temperatures. The climate of the area can be characterized as arid and semiarid regions. It has an irregular rainfall of less than $300 \mathrm{~mm}$ per year in which potential evapotranspiration exceeds precipitation [20]. Hence, water shortage leads to the natural salinization process, resulting in soil degradation and contributing to desertification.

Germination is considered as the most sensitive stage of the plant life cycle. The first physiological disorder, which takes place during germination, is the reduction in imbibitions of water by seeds, which leads to a series of metabolic changes, including changed enzyme activities and general reduction in hydrolysis and utilization of the seed reserve [29]. Tolerance to salinity during germination is critical for the establishment of plants growing in arid saline soil regions [31]. In such regions, germination occurs during the rainy season when soil salinity levels are usually reduced [8]. Salinity inhibits germination of plant seeds in one of the two ways: (1) preventing germination without loss of viability at higher salinities; and (2) delaying germination of seeds at salinities that cause some stress to seeds but do not prevent germination.

Lygeum spartum seeds showed highest germination percentages under nonsaline conditions. An increase in salinity inhibited germination; however, about $20 \%$ of the seeds germinated at $150 \mathrm{mM} \mathrm{NaCl}$ (Fig. 3). These results indicate that $L$. spartum is a moderately salt-tolerant grass at germination stage in comparison with other grasses found at the steppes of Algeria. Similar results were reported for other grasses: Briza maxima [21], Triglochin maritima [18], Aeluropus lagopoides [10], and Sporobolus ioclados [19].

Nedjimi [25] found that $L$. spartum was able to grow in medium containing $100 \mathrm{mM} \mathrm{NaCl}$ without displaying saltinduced toxicity symptoms, and fresh and dry weights of shoots and roots reduced significantly above $50 \mathrm{mM} \mathrm{NaCl}$. 
Fig. 2 Cumulative germination percentage of $L$. spartum seeds during 15 days at different temperatures as influenced by $\mathrm{NaCl}$ concentrations $(0,50,100$, and $150 \mathrm{mM})$ and incubation temperatures $(10-20,15-25$, and $20-30{ }^{\circ} \mathrm{C}$ )

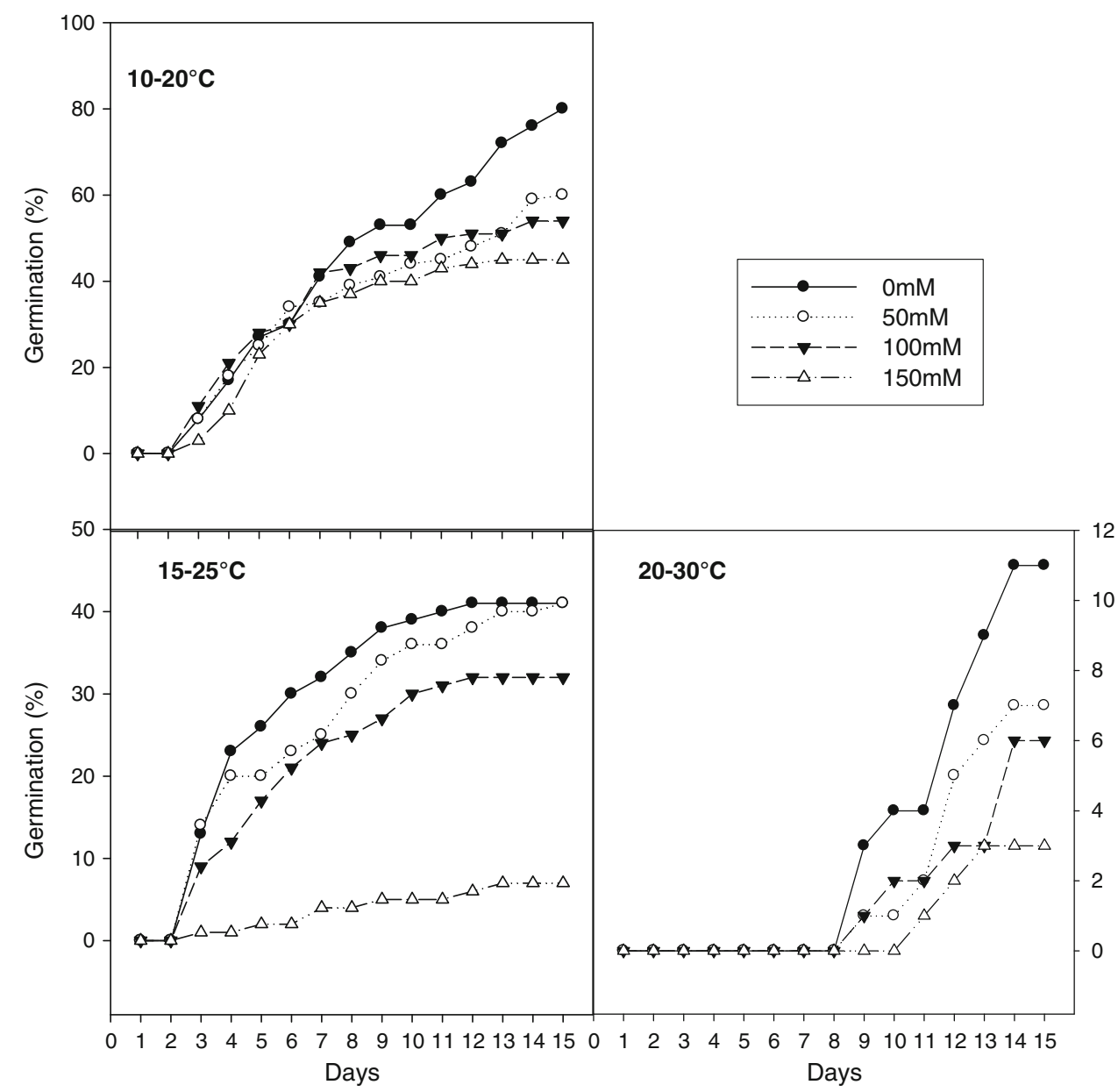

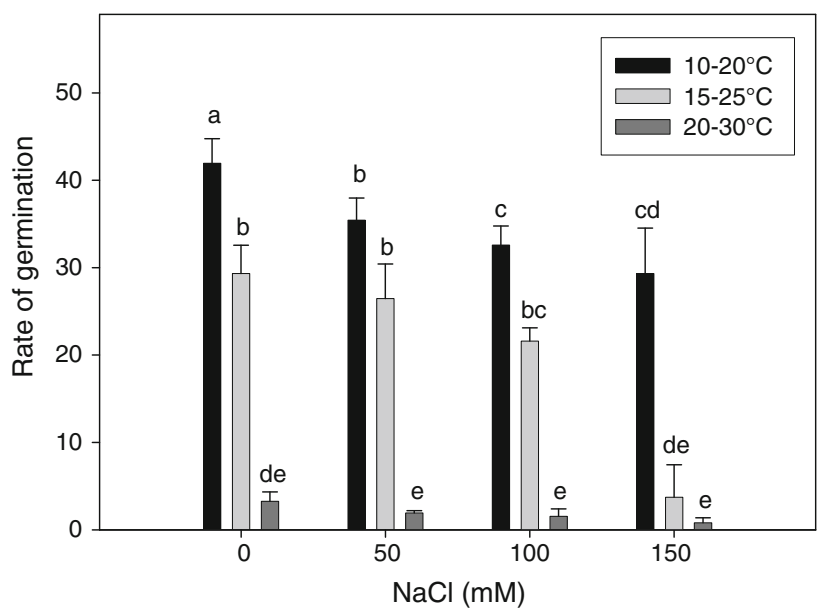

Fig. 4 Effect of $\mathrm{NaCl}(0,50,100$, and $150 \mathrm{mM})$ and temperature (10-20, 15-25, and $\left.20-30^{\circ} \mathrm{C}\right)$ on rate of germination of $L$. spartum. Bars represent mean \pm SE $(n=4)$. Different letters indicate significant difference between treatments (Tukey's test $P<0.05$ )

osmotic adjustment. It can tolerate low soil $\mathrm{pH}$ from 3 to 4 because of mycorrhizal associations, thus maximizing the use of scarce nutrients [5]. Moreover, it accumulates salt ions in tissues, which adjusts leaf water potential, enabling 
Table 2 Recovery percentage (mean $\pm \mathrm{SE}$ ) of germination of $L$. spartum after they were transferred from $0,50,100$, and $150 \mathrm{mM}$ $\mathrm{NaCl}$ to distilled water at thermoperiods of 10-20, 15-25, and $20-30{ }^{\circ} \mathrm{C}$

\begin{tabular}{lcrc}
\hline $\mathrm{NaCl}(\mathrm{mM})$ & \multicolumn{3}{l}{ Thermoperiod $\left({ }^{\circ} \mathrm{C}\right)$} \\
\cline { 2 - 4 } & $10-20$ & $15-25$ & $20-30$ \\
\hline 0 & - & - & - \\
50 & $37.5 \pm 1.91 \mathrm{~b}$ & $20.5 \pm 5.45 \mathrm{~cd}$ & $19.5 \pm 3.42 \mathrm{~cd}$ \\
100 & $58.25 \pm 7.23 \mathrm{a}$ & $27.25 \pm 2.99 \mathrm{c}$ & $15 \pm 2.58 \mathrm{~d}$ \\
150 & $64.25 \pm 5.56 \mathrm{a}$ & $42 \pm 3.27 \mathrm{~b}$ & $12.25 \pm 1.71 \mathrm{~d}$ \\
\hline
\end{tabular}

Different letters in the same column indicate significant difference at $P<0.05$ according to the Tukey's multiple range test

the plant to maintain cell turgor and limit transpiration under saline conditions. In addition, significant increase in glycine betaine and valine has been noted at $100 \mathrm{mM} \mathrm{NaCl}$ $[23,25]$. In salt stress condition, the leaf water relations were characterized by low osmotic potential and low root hydraulic conductivity [24].

Sensitivity to periodic temperature and salinity fluctuations constitutes an important mechanism, which enables plants to respond to daily variations in the soil surface conditions. Temperature shifts may affect a number of processes determining the germinability of seeds, including membrane permeability, activity of membrane proteins, and cytosol enzymes [3]. Germination of seeds in salt soils usually occurs after monsoon rains when there is a reduction in temperature and soil salinity [10]. Salinity and temperature interact with their control of seed germination, and the greatest inhibition is usually found at the maximum and minimum limits of tolerance of these two environmental variables, as reported in Hordeum jubatum [2], and Urochondra setulosa [11].

The effect of salinity on germination varies considerably with temperature regimes [17]. Guma et al. [12] reported that a temperature regime of $10-20{ }^{\circ} \mathrm{C}$ is optimal for seed germination of Salsola vermiculata, whereas $25-30{ }^{\circ} \mathrm{C}$ was the upper threshold temperatures for seed germination. Our data showed that the $10-20{ }^{\circ} \mathrm{C}$ thermoperiod is the most favorable for germination of $L$. spartum. In the natural habitat of the population studied, such temperatures can occur after seed dispersal during late autumn and winter, in coincidence with the rainfall period (November-February). At this time of the year, seeds are exposed to cooler temperatures and low salinity in the soil and these conditions may enhance germination.

The response of seeds of $L$. spartum transferred to distilled water after 15 days at various salinities varied depending on the temperature regime. Seeds exposed to higher salinity recovered quickly at cooler temperatures $\left(10-20{ }^{\circ} \mathrm{C}\right)$. Recovery of germination responses was also dependent on temperature, ranging from $12 \%$ recovery at $20-30{ }^{\circ} \mathrm{C}$ to $64 \%$ at $10-20{ }^{\circ} \mathrm{C}$ (Fig. 4). Under highest saline conditions, seed survival rather than germinability may be an appropriate criterion for success, since recovery of germination does occur in seeds of $L$. spartum and other halophyte grasses when hypersaline conditions are alleviated [31]. Dormancy reduces the risk of seedling mortality, when moisture is limited and salinity is increased. This is quite favorable under hypersaline conditions [19].

\section{Conclusions}

From the present results, it is evident that seeds of $L$. spartum germinate better at low temperature $\left(10-20{ }^{\circ} \mathrm{C}\right)$. Salt stress decreases both rate and percentage of germination, but recovery was higher under cooler thermoperiods. In field conditions, seeds present in the soil are exposed to cooler conditions and low salinity during the late autumn and winter, and this situation may enhance the germination and recruitment earlier in the season. However, seeds would still not be able to germinate when conditions get warmer. It appears that better recovery response at cooler temperatures confers on the advantage of preempting sites before other species could germinate, and this would give L. spartum an excellent opportunity to successfully colonize. Therefore, to increase the probability of successful plant establishment in rehabilitating of degraded lands in Algerian steppes, germination requirements should be considered in the planning of sowing dates. According to our findings, late autumn and winter sowings would be recommended, when salinity and temperature stresses are reduced after the first rains of the season.

Acknowledgments This research was financially supported by Algerian Ministry of Higher Education and Scientific Research (PNR Project No. 1/U7/7606).

\section{References}

1. Baba Aissa F (2000) Encyclopédie des plantes utiles, flore d'Algérie et du Maghreb. Librairie moderne, Alger

2. Badger KS, Ungar IA (1989) The effects of salinity and temperature on the germination of the inland halophyte Hordeum jubatum. Can J Bot 67:1420-1425

3. Bewley JD, Black M (1994) Seeds: physiology of development and germination. Plenum Press, London

4. Conesa HM, Robinson BH, Schulin R, Nowack B (2007) Growth of Lygeum spartum in acid mine tailings: response of plants developed from seedlings, rhizomes and at field conditions. Environ Pollut 145:700-707

5. Díaz G, Honrubia M (1995) Effect of native and introduced arbuscular mycorrhizal fungi on growth and nutrient uptake of Lygeum spartum and Anthyllis cytisoides. Biol Plant 37: 121-129 
6. Djabeur A, Kaid-Harche M, Khelifi D (2008) Proteins polymorphism of some populations of Lygeum spartum L. in Algeria. Am J Agric Biol Sci 3:337-341

7. Djabeur A, Kaid-Harche M, Côme D, Corbineau F (2010) Environmental control of germination and dormancy of seeds of two cytotypes of Lygeum spartum L., a perennial grass of semiarid and arid areas in Algeria. Ecol Mediterr 36(1):89-98

8. EL-Keblawy A (2004) Salinity effects on seed germination of the common desert range grass, Panicum turgidum. Seed Sci Technol 32:943-948

9. Gharaibeh MA, Eltaif NI, Albalasmeh AA (2011) Reclamation of highly calcareous saline sodic soil using Atriplex halimus and byproduct gypsum. Int J Phytorem 13:873-883

10. Gulzar S, Khan MA (2001) Seed germination of a halophytic grass Aeluropus lagopoides. Ann Bot 87:319-324

11. Gulzar S, Khan MA, Ungar IA (2001) Effect of salinity and temperature on the germination of Urochondra setulosa. Seed Sci Technol 29:21-29

12. Guma IR, Padrón-Mederos MA, Santos-Guerra A, Reyes-Betancort JA (2010) Effect of temperature and salinity on germination of Salsola vermiculata L. (Chenopodiaceae) from Canary Islands. J Arid Environ 74:708-711

13. Halitim A (1988) Arid soils in Algeria. OPU, Alger

14. Harche M, Chadli R, Catesson AM (1990) Diversity of cellulose micro fibril arrangement in the cell walls of Lygeum spartum leaves. Ann Bot 65:79-86

15. Harche M, Tollier M, Monties B, Catesson AM (1991) Caractérisation comparée des constituants (polyosides, lignines et acides phénoliques) des parois cellulaires de trois Graminées subdésertiques pérennes: Stipa tenacissima L., Lygeum spartum L. et Aristida pungens L. Cell Chem Technol 25:11-17

16. Khadhri A, Neffati M, Smiti S (2011) Germination responses of Cymbopogon schoenanthus to salinity. Acta Physiol Plantarum 33:279-282

17. Khan MA, Ungar IA (1996) Influence of salinity and temperature on the germination of Haloxylon recurvum Bunge ex. Boiss. Ann Bot 78:547-551

18. Khan MA, Ungar IA (1999) Seed germination and recovery of Triglochin maritima from salt stress under different thermoperiods. Great Basin Nat 59:144-150
19. Khan MA, Gulzar S (2003) Germination responses of Sporobolus ioclados: a saline desert grass. J Arid Environ 53:387-394

20. Le Houérou HN (1995) Bioclimatologie et biogéographie des steppes arides du nord de l'Afrique. Diversité biologique, développement durable et désertisation. Opt Méditerr 10:1-396

21. Lombardi T, Fochetti T, Onnis A (1998) Germination of Briza maxima L. seeds: effects of temperature, light, salinity and seed harvesting time. Seed Sci Technol 26:463-470

22. Meot-Duros L, Magné C (2008) Effect of salinity and chemical factors on seed germination in the halophyte Crithmum maritimum L. Plant Soil 313:83-87

23. Nedjimi B (2009) Salt tolerance strategies of Lygeum spartum L.: a new fodder crop for Algerian saline steppes. Flora 204:747-754

24. Nedjimi B, Daoud Y, Carvajal M, Martínez-Ballesta MC (2010) Improvement of the adaptation of Lygeum spartum L. to salinity under the presence of calcium. Commun Soil Sci Plant Anal 41(19):2301-2317

25. Nedjimi B (2011) Is salinity tolerance related to osmolytes accumulation in Lygeum spartum L. seedlings? J Saudi Soc Agric Sci 10:81-87

26. Nedjimi B (2012) Rangeland improvement and management options in the arid steppes of Algeria. In: Germano MD (ed) Steppe ecosystems: dynamics, land use and conservation. Nova Science Publishers, New York, pp 157-170

27. Rogel JA, Silla RO, Ariza FA (2001) Eedaphic characterization and soil ionic composition influencing plant zonation in a semiarid Mediterranean salt marsh. Geoderma 99:81-98

28. Sharma TP, Sen DN (1989) A new report on abnormally fast germinating seeds of Haloxylon spp.- - an ecological adaptation to saline habitat. Curr Sci 58:382-385

29. Sidari M, Mallamaci C, Muscolo A (2008) Drought, salinity and heat differently affect seed germination of Pinus pinea. J For Res 13:326-330

30. Timson J (1965) New method of recording germination data. Nature 207:216-217

31. Ungar IA (1995) Seed germination and seed-bank ecology of halophytes. In: Kigel J, Galili G (eds) Seed development and germination. Marcel Dekker Inc., New York, pp 599-629 